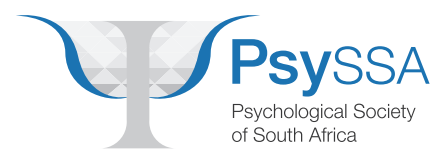

\title{
Three Pathways for Enlarging Critical African Psychology
}

\author{
Kopano Ratele ${ }^{1,2}$ (D), Nick Malherbe ${ }^{1,2}$, \\ Shahnaaz Suffla ${ }^{1,2}$, Josephine Cornell ${ }^{1,2}$ \\ and Naiema Taliep ${ }^{1,2}$
}

\begin{abstract}
Departing from the position that critical African psychology is an endeavour whose objective is to harness psychological knowledge in, by, for, and with Africa, as well as the world, but also to critically think Africa into psychology, this article considers space as a key idea to consider in the further development of African psychology, and more specifically, a critically inclined African psychology. Taking critical African psychology as one of the orientations within Africa(n)-centred psychology, we argue for constructing and enlarging space so as to resist ruling epistemes in psychology in and of Africa and to create oppositional spaces that adduce alternative readings and makings of psychology-in-place. We outline three pathways, namely, (I) collective thinking and writing, (2) transdisciplinarity, and (3) affective community building, via which to realise and work from a critical African psychological position. These by no means exhaust all the pathways that can be charted by critical African psychologists and are instead offered as illustrations with which our collective has been engaging, thinking together, and experimenting.
\end{abstract}

\section{Keywords}

Affective community building, collective writing, critical African psychology, epistemic independence, psychosocial liberation, space, transdisciplinarity

Critical African psychology is an endeavour whose objective is to harness psychological knowledge in, by, for, and with Africa, as well as the world. Critical African psychology also seeks to critically think Africa into psychology (Ratele, 2019). Such a project - although not eschewing universalisms or (critical) psychologies forged in the Global North - explicitly rejects those psychologies which are (usually implicitly) developed for the North, all while claiming universality.

\footnotetext{
'Institute for Social and Health Sciences, University of South Africa, South Africa

${ }^{2}$ Masculinity and Health Research Unit, South African Medical Research Council, South Africa
}

\section{Corresponding author:}

Kopano Ratele, Masculinity and Health Research Unit, South African Medical Research Council, Cape Town, PO Box 19070, Tygerberg, 7505, Western Cape, South Africa.

Email: kopano.ratele@mrc.ac.za 
Taken as an orientation and a dynamic field of activity, critical African psychology operates as a mode of engagement that already exists in subaltern knowledge alongside dominant forms of critical psychology, but also as a future-oriented praxis. This mode is supported by a history of local, continental, and global contributions that aim to unsettle ruling psychologies and local authoritarian structures, as well as enact a critical attitude in socially transformative work. Hence, critical African psychologists face the challenge of defining what critical African psychology is, while at the same time resisting, crossing, and expanding into a number of epistemic terrains, including those inhabited by conservative African psychology, hegemonic Euroamerican psychology, Euroamerican critical psychology, as well as others that may not be familiar to some psychologists, but are nonetheless essential to our own understanding of psychology.

It has been said that critical psychology emerged from critical theory in Europe, which was derived primarily from the so-called 'masters of suspicion' (i.e., Marx, Nietzsche, and Freud) in the 19th century and the Frankfurt School in the 20th century (Teo, 2015). This work was developed as a response to the determination of mainstream psychology as a 'problematic science' concerned with control, adaptation, and oppressive state practices (Teo, 2009). There have, however, always been global varieties of critical psychological work (Teo, 2015). On the African continent, from which we write, such critical psychological work has been influenced by a plethora of anti-colonial thinkers, including Fanon, Césaire, and Senghor, as well as other African critical intellectuals and political figures, like Ngũgĩ, Mkandawire, Hountondji, Sankara, Biko, Mudimbe, and Alexander. We consider critical psychology in Africa as aimed at understanding psychology and society in relation to colonialism, racism, apartheid, and coloniality, which therefore includes locating psychological work within projects of anti-racism and decolonisation (Fanon, 1967a, 1967b; Teo, 2015). For critically inclined psychologists all over the world, then, psychology represents both the object of and tool for psychosocial critique. Although far from a coherent body of work (Ratele et al., 2018; Fanon, 1967a, 1967b; Hook, 2004; Parker, 2007; Teo, 2015), critical psychology sets out to counter the characterisation of psychological health, pathology, individuals, and groups among others - through an exclusively individualising hermeneutic. It is in this mould that a critical African psychology comes to be leavened as a politico-intellectual, ethical, and epistemological project with radical possibilities for praxis.

The story of the origins of critical psychology, like all stories of origin, has to be approached with a sceptical attitude, not least because it is a story about a critical psychology as much as it is also a story about Europe. Like acritical mainstream psychology, much critical psychology continues to root itself in epistemologies, methodologies, and theories that speak only in a perfunctory manner - if they speak at all - to the Global South, and Africa in particular (Ratele, 2019; Teo, 2015). Save for the contributions of a few scholars, knowledge-making, knowledge forms, knowledge, and the consequences of knowledge outside of the Global North remain largely ignored by critical psychology. This neglect can result in an unwitting psychic mode of coloniality (Manganyi, 1973; Mudimbe, 1988). Herein lies a central challenge - or perhaps contradiction - of critical psychology that instantiates or reinforces the necessity for a critical African psychology, intended here as a better situated psychology.

It should also be noted that there are varieties of critical approaches globally. In Latin America, Martín-Baró's (1994) critical theories and practices, which constituted part of his liberation psychology, have had a larger influence than European critical psychology, and post-colonial and decolonisation discourses have played a significant role in South Africa (Hook, 2005). Indigenous psychologists including Enriquez (1992), who developed a uniquely Filipino psychology, have also contributed towards the development of a critical approach in psychology. Indeed, there exist critical programmes that may not use the label of critical psychology (Montero \& Sonn, 2009): Feminist psychologists criticise the mainstream as being gender biased (Rutherford et al., 2011); 
social-constructionist academics are critical of a traditional understanding of language in psychological work (Danziger, 1997; Gergen, 2009); and post-colonial programmes in psychology attempt to understand psychology in the context of colonialism (e.g., Bhatia, 2002; Moane, 1999). Some hermeneutic inspired approaches emphasise critical thinking about mainstream or traditional psychology (Slife et al., 2005), and some forms of cultural psychology share a family resemblance with critical psychology (Valsiner \& Rosa, 2007).

As a praxis and perspective that is critical of mainstream African psychology - as well as a Western-centric, critical psychology - critical African psychology is willed towards a fundamentally humanising, political, and ethical set of practices that bring notions of psychosocial liberation into social, economic, political, cultural, epistemic, and interpersonal justice. To this end, in an effort to alter what is considered to be legitimate psychological knowledge and practice, critical African psychology draws intersubjective, epistemic, cultural, political, and economic projects into the psychological. And, taking African as the primary locus of thought, critical African psychology asserts contributions from and for Africa within a global context where such contributions are often rendered inauthentic, emerging, and/or puerile (Masaka, 2018).

By elucidating potentialities for both the form and content of critical African psychology, we attempt in this article to clarify what critical African psychology is (meaning not its essence but rather it has and can become in practice), drawing out three pathways, and to what ends it can be used to enlarge space. We begin by interpreting how critical African psychology as an orientation within African psychology constitutes a psychology whose useful value is rooted in the histories, political economies, knowledge, and psychosocial problems of Africa. Following this, we offer three spatialised pathways for the building and enactment of critical African psychology, all of which orbit around the idea of space. This is by no means an exhaustive list of all the pathways that can be charted by critical African psychologists. Rather, we offer these pathways as three distinct - but related - illustrations with which our collective has been engaging, thinking together, and experimenting. We name these three spatial pathways collective thinking and writing, transdisciplinarity, and affective community building. Considered together, they are intended to negate notions of critical psychology as little more than a deconstructive endeavour, pointing instead towards the development of a critical African psychological praxis.

\section{Critical African psychology as an orientation within Africa(n)- centred psychology}

By way of conceptual clarification, a distinction is to be made between African psychology and Africa(n)-centredness. According to Ratele (2017),

The former ought to be taken as referring to a broad category of the body of knowledge and practices that encompasses all of what psychologists in, or in relation to, Africa do. The latter is a small part of the former. The distinction is about orientation towards 'African' and 'psychology'. (p. 316)

Hence, 'all of psychology concerning Africa or Africans' is African psychology (Ratele et al., 2018 , p. 333). African psychology thus occupies a broad epistemic terrain concerning the psychological as it relates to Africa, whereas Africa(n)-centred psychology is regarded as one part of this knowledge expanse. Africa(n)-centred psychology (or African psychology in the strict sense) is itself further divided into distinctive orientations (see Ratele, 2019).

Speaking to the distinction between African psychology as an expansive terrain and Africa(n)centred psychology as one aspect of this broad epistemic landscape, Ratele (2017) has proposed a framework of orientations that may be employed in diverse settings, including research, teaching, 
community building, therapy, socio-political activism, and theory production (many of which have not always been considered the 'proper' place of psychology or psychologists). Critical African psychology is one of the four orientations he proposed. By this, he indicated a critically minded, materialist, or structuralist African psychology. As a collective, we have chosen to include poststructuralist concerns as part of this orientation. However, it is in these ways that critical African psychology has come to occupy an (ever-expanding) epistemological space. Taking critical African psychology forward requires that we expand this epistemic space into the very physical spaces within which we enact this psychology.

Ratele (2017) regards critical African psychology as a transdisciplinary orientation, reaching beyond received psychology to other disciplines, knowledge, and critical practices (for more on this framework, see Ratele, 2019). The idea of critical psychology, whether Latin American, Euroamerican, Asian, or African, as a praxis, position, approach, stance, or orientation instead of discipline per se, is shared with other critically minded psychologists (see Hook, 2004). Thus, critical African psychology can be understood as an orientation towards general relations of power; towards economic and political relationships between the West and the Global South (broadly) and Africa (particularly); towards representations about Africa and Africans; and towards psychology.

In what follows, we outline three pathways through which to realise and work from a critical African psychological position. The three pathways on which we have chosen to focus here are (1) collective thinking and writing, (2) transdisciplinarity, and (3) affective community building. Before elaborating on the pathways, we offer an interpretation of space as it is referential to critical African psychology (the intention being the amplification of the space within which critical African psychology is materialised).

\section{Enlarging space: three pathways for critical African psychology}

Psychology has traditionally privileged time over space as an organising principle for scholarship and practice. Despite the 'spatial turn' within the social sciences and humanities more broadly, and an increasing pivot towards spatial theorising outside of the discipline of geography (Soja, 2009), both mainstream and more critical iterations of psychology have often ignored the notions of place and space (Dixon \& Durrheim, 2000) as central axes of epistemological and ontological locatedness that entreat recuperations, alliances, disruptions, and enlargements. From the vantage of critical African psychology, material space is inherently social (under which we include the political), for it is always underpinned by the dominant ideologies of the time, as it is engendering of profound social (incorporating historical, material, cultural, symbolic, and political) implications for individuals and communities. Refuting colonially forged renderings of space as ahistorical and static, and as a resource to be charted, collected, categorised, conquered, and claimed (Massey, 2005; Valentine, 2001), critical African psychology pronounces - precisely for this reason - that constructions and engagements of space represent a key site of economic, cultural, and political struggle; activism; and change (see Neely \& Samura, 2011). As such, critical African psychology is interested in deploying space as historically contingent, yet fluid; as systemically infused in power relations, yet capable of inscribing new cartographies of power; and as more faithfully signifying the knowledge, social, material, and relational edifices of African lives, yet pluralised in constitution.

Here then, enlarging space is to resist ruling epistemes in psychology in and of Africa, as much as it is to acknowledge differences in psychology concerning Africa, and, critically, to create capacious spaces that house varieties of readings and makings of psychology-in-place. For critical African psychology, such prefigurative spatiality, as ideological and onto-epistemological production (see Lefebvre, 1991), represents intentional and liberatory efforts that privilege differently 
historied knowledge, practices, traditions, and people. From this position, critical African psychology seeks to chart a trajectory that is self-consciously African and draws into its analyses the spatialised ways in which thought and affect are inscribed, materialised, and practised. Albeit layered, complex, and partial, expanding in this way the space within which critical African psychology is enacted aspires to the idea of Africa (see Mudimbe, 1994), explicitly conceived in and inviting critical imaginaries from Africa and for Africa and the world.

\section{Thinking together, writing together}

In the preface to what is surely his masterwork, Walter Rodney (1982) provocatively insists that

contrary to the fashion in most prefaces, I will not add that 'all mistakes and shortcomings are entirely my responsibility'. That is sheer bourgeois subjectivism. Responsibility in matters of these sorts is always collective, especially with regard to the remedying of shortcomings. (p. vii-viii)

Rodney, it would seem, is hyper-aware that all thinking and writing is, in effect, the product and responsibility of the collective. As humans, we are unable to think - indeed to know - beyond the ever-shifting and intertwined assemblage of temporal, biological, cultural, intergroup, national, and globalised forces in which we are ensnared. Accordingly, thinking and writing in an explicitly collective manner is useful in debunking the myth that knowledge creation is an isolated or purely individual affair that is the sole privilege of the academic. Hence, one of the gifts critical African psychologists can offer critical psychologists - and surely all psychologists - around the globe is charting paths towards unthinking knowledge and its making as a product of the detached mind of the Master Thinker. As this myth continues to be rewarded by neoliberal authorship metrics, acknowledging the collective - within and without the academy - in thinking and writing is propelled by a political and epistemological impetus that extends beyond merely publishing for its own sake.

As a collective of senior and junior researchers working in an institutional space, we argue that collaborative thinking and writing can serve to expand notions of criticality in the construction and elaboration of critical African psychology. This means we are able to construct critical African psychology through carving out material, epistemic, and praxical spaces within institutionalised enclosures from which to enact this project. Physical spaces of this kind, within which we can communally write and think about critical African psychology, are important in building such a psychology, such that it begins to occupy a variety of spaces, such as clinical practices, community health centres, and university curricula.

For us, collaborative thinking and writing are realised in the fraught process of writing individual voices (themselves always an amalgamative product of thinking) into a collective. In this way, various subjectivities, interpretive languages, and experiences coalesce in the thinking toand-fro and writing event to create assemblages of people, ideas, places, thoughts, images, and objects (Woodward \& Phillips, 2019). Although often rewarding, this way of writing (which is, at once, also a mode of thinking and theorising) necessitates a degree of psychological discomfort, defence, and conflict, all of which contribute to a dialectical process of learning and teaching that changes the product being enunciated (i.e., critical African psychology) through its very enunciation. One's conception of the possibilities and limitations of critical African psychology are then usually altered when they are considered through a prism of a spatially situated collective. In short, we think and we write to invent different ways of relating, loving, feeling, moving in space, and ways of being here as well as elsewhere. Although writing can invent different modalities of thinking, it can also create new ways of moving, feeling, and making (Woodward \& Phillips, 2019). 
While never as linear or even as democratic as we might wish it to be, collective writing is able to disrupt epistemic and relatedly ontological hierarchies of thinking, wherein a space is created that encourages each author to challenge the other, all while acknowledging and making use of the different strengths and weaknesses within a particular writing group. It is through this sort of epistemic disruption that we can begin to pry open different possibilities for critical African psychology, with individual authors - as well as their writing and thinking - undergoing a degree of transformation (Wyatt \& Gale, 2014).

While we believe that collective thinking and writing in the same physical space gives rise to a richer communal atmosphere, such a space is never assured. Indeed, some authors might have prior commitments or may work at a considerable distance from each another. Others still may experience technological problems that inhibit communication with the collective, all while global forces work to hinder collaboration (the recent COVID-19 pandemic is certainly a pertinent example here; however, more historically entrenched and structurally violent social systems also play a part). Thus, the physical spaces in which we conduct critical African psychology influence its epistemic spatial contours. This space should connotate safety for individuals within the collective. They should also enable each thinking writer to push the other to assess, reevaluate, and critique how critical African psychology is understood, and to reimagine what the political potential for such a psychology could be. Although collective thinking and writing are certainly not the exclusive products of critical African psychology, we posit that, together, they present a useful methodological form for advancing critical African psychology. In addition, collective writing and thinking is able to offer critical African psychology an organic means through which to begin thinking transdisciplinarily.

\section{Transdisciplinarity}

Critical African psychology is a transdisciplinary praxis. A compound term that denotes that something or someone crosses, shifts, travels, moves, or changes from one state, form, thing, moment, or place to another; trans urges critically minded African psychology students and professionals to go beyond the metaphorical walls of disciplines of traditional Euroamerican psychology and conservative African thought. Whereas some of its tentacles are in psychology, as a transdisciplinary stance, critical African psychology is constituted by a moving desire to transcend, transform, and transgress the bounds of mainstream and critical Euroamerican-centralising psychology.

The dynamic, rapidly changing, and cross-boundary nature of intertwined technological, biological, social, health, and psychological problems - climate change, automation, big data, and again, pandemics can be adduced as examples - demands answers that often lie beyond the ken of traditional disciplinary tools of psychology. Transdisciplinarity, as a lens and way of working that leaps over, undermines, alters, defies, and quite often rejects the restrictions of received disciplinary boundaries, may be better positioned to be more responsive and innovative in many such instances. And, unlike interdisciplinarity or multidisciplinarity (both of which temporarily bring together those with shared interests but, in an attempt to locate 'cross over', leave unchanged the respective disciplines involved), transdisciplinarity, given the risks it takes and its awareness of its limits, fundamentally metamorphoses how disciplinary orthodoxies are understood and employed, thus creating knowledge that is novel, transgressive, and provisional while being problem focused. Indeed, Sehume (2013) notes that transdisciplinarity is always contingent and non-essentialising and, therefore, rejects the politics of differentiation and exclusion upon which the bordering and disciplining of knowledge depends. Transdisciplinarity, he argues, is symbiotic and embraces epistemic pluralism. For instance, Fanon's (1967a, 1967b) embrace of transdisciplinarity saw him bringing into his psychiatric practice continental philosophy, psychology, political science, history, 
economics, and even anecdote, all of which fundamentally transformed how we understand the disciplinary borders as well as the social capabilities of psychiatry. Critical African psychology calls for, indeed provokes us to bring into, psychological work and African spaces, 'strange' ideas, new tools, ingenious ways of thinking, and 'foreign' practices with the goal of making sense of and overcoming the problems we face in our situatedness.

There is certainly not an absence of transdisciplinary work in African scholarship, as is shown by a close reading of the historiography of transdisciplinarity. Many progressive scholars within studies of Africa have long resisted the epistemic homogeneity imposed by hegemonic knowledge systems, promoting instead - as a critical strength - the creation of (counter) spaces between, across, and beyond disciplines where fresh questions are posed, new approaches advanced, original interpretations offered, and alternative intellectual topographies emerged (Zeleza, 2006). The omission of African-situated transdisciplinary work from the Western canon and mainstream discourses on transdisciplinarity may very well explain why, for the most part, psychology in Africa has been slow to eschew intellectual territoriality and the struggle for disciplinary power and resources. Here, then, psychology's pitfall has been to fasten itself to narrow and reductive disciplinary rubrics, or 'disciplinary decadence' (see Gordon, 2007). If this limitation is indeed as we contend, then a critical African psychology - recalling marginalised histories of transdisciplinarity on the continent itself and its travelling thinkers - seeks to extend its epistemic frontiers through hermeneutic dialogue and transgressive encounters with collectives of critical, anarchist, and radical thought to expand the ways by which its liberatory potential may be realised. Enlarging space as such is to accord primacy to thought and praxis that not only counters the oppressive logics to which much of psychology in Africa remains yoked but also cultivates 'epistemic openness and radical political receptiveness' as it reorients transdisciplinarity itself towards a 'transdisciplinary human science with emancipatory intent' (Rabaka, 2010, p. 355).

Importantly, traversing disciplinary territories and fostering spaces of epistemic openness must necessarily expand beyond spatial metaphor towards the creation of both intellectual and material spaces. Transdisciplinarity as a materialising paradigm is represented through the presence of our bodies in plural and hybrid (and increasingly virtual as the latest pandemic reshapes academic, political, and social landscapes) spaces and undertakings, such as conferences, community engagement, research, intervention delivery, counselling, training, media work, policy, and activism, that explicitly seek and favour the permeability of disciplinary limits. The transformative agency of transdisciplinarity is thus affixed to and embedded within the very physical spatial practices of critical African psychology. Through this transdisciplinary attitude, critical African psychology considers affect somewhat differently to many of the ruling psy-disciplines.

\section{Affective community building}

Like Neville Alexander (2013), we understand organic intellectuals, a Gramscian term, to refer to those who attempt to better understand psychosocial ills so that they are able to enact a politically informed mode of social action. Within critical African psychology, psychologists - as well as those with whom psychologists work - can be thought of as organic intellectuals. We wish to argue that organic intellectuals who are oriented towards critical African psychology should concern themselves with the connections between psychic and political life. One of the ways by which such organic intellectuals (e.g., psychologists, community members, and students) can do this is by engaging with orders of feeling. Thomas Stodulka (2019, p. 310) explains that orders of feeling denote the 'discursive orders that leave their marks on individual and collective appraisals of feelings, and they shape socially, culturally, and politically proscribed feeling and display rules'. Although similar to structures of feeling, a concept developed by Raymond Williams (1977) to 
refer to the power differentials which shape the ways that different groups experience affect, orders of feeling are always situated in dynamic social contexts and imply shifting hierarchies that speak to how structures influence individuals in situ (Stodulka, 2019). Accordingly, orders of feeling are always classed, raced, and gendered, seeking to denote how, when, if, and where the gendered, raced, and classed subject is able to feel.

Affect serves as a useful entry point into interrogating orders of feeling. By understanding affects as the everyday embodied feelings mediated by various social factors (Young \& Gilmore, 2013), critical African psychologists concerned with orders of feeling can begin to co-create innovative spaces that engender and identify the kinds of affects to which we must attend if we are to make sense of people's material realities (Canham, 2018). Similarly, psychologists should seek to interrogate their own affective ideals which may - at different moments - cohere with and resist oppressive orders of feeling. As feelings do not encompass a linear, narrative form, people can have spaces in which to articulate affect, together, in innovative ways. Such articulation endeavours to speak back to various orders of feeling and the ways by which particular feelings are classed, raced, and gendered.

Affect, and its constitution within orders of feeling, plays an important, yet under-appreciated, role in community building, a core concern for the organic intellectual (see Alexander, 2013). To reference an illustration from our work, in 2011, the University of South Africa Institute for Social and Health Sciences initiated a community-engaged research project, Spiritual Capacity and Religious Assets for Transforming Community Health by Mobilising Males for Peace and Safety (SCRATCHMAPS), which saw members of collaborating communities work with psychologists to co-create a participatory, social-psychological space that privileged the articulation and mobilisation of collective affects for the purpose of community building. In addition to multiple community-engaged research activities, this space comprised particular affect-related work, including community connectedness and trust, weekly meetings that always comprised a participatory reflexive, frequently highly affective, check-in and debriefing check-out processes to ensure that all voices were affirmed, and witnessing emotional, often disturbing articulations of experience and resistance during historical time-line exercises when recounting how particular historical injustices affected the individual and collective psyche of community members. There are two important points that we want to highlight here. First, within these spaces, community members and psychologists as organic intellectuals sought to connect affectively with one another as nurturers, co-learners, mutual sharers, and co-producers of ideas, writing, and action. Second, affect has the proclivity to engender action, which is noted in how community members drew on their shared affects, as well as empathetic affective engagements, to institute various community action initiatives. For example, as an outcome of the SCRATCHMAPS project, community members started a men's support group, thus creating a safe space to connect, articulate feelings, reflect on shared experiences, provide emotional support, and identify appropriate strategies to deal with family challenges caused by and affecting men. Within the space, community members sought to resist 'affective practices that construct and shape local orders of feeling' and which conform to gendered norms of affect, and that seek to determine who can voice particular emotions to whom, and in which contexts and spaces (Stodulka, 2019, p. 312).

Work of this kind draws together multiple experiences that challenge oppressive social and psychological structures, ideas and affects, initiating transformation that can allow people to 'become the [social change agents and] mouthpiece of a new reality in action' (Fanon, 1967b, p. 179). In this respect, affect and social justice cohesively reinforce one another. There is a conscious, explicit focus on an action-oriented and affective sense of connectedness here, whereby 'structures of social and psychic domination' are resisted, and the 'making of solidarity' is understood as an 'active achievement, the result of active struggle' (Mohanty, 2003, p. 7). In short, 
critical African psychology is able to create or usher the kinds of spaces wherein people are able to harness emotional resources in working together to influence their material realities, which is especially powerful in cases where affective control is systemically exerted over people's lives (see Stodulka, 2019).

\section{Conclusion}

In this article, we have described and elaborated on a critical African psychology. In the same breath, the intention has been to further diversify and reorient psychology (and critical psychology in particular) from its pseudo-universalist, Western ethnocentric truth claims towards more pluriversal, situated praxes, offering pathways to think about and do psychology with critical lenses from the vantage of places in Africa. To oppose the dominance of Western- or Euroamericanethnocentrism is of course not to be anti-West, anti-European, or anti-American. On the contrary, a critically minded African psychology pays close attention to the social, political, and economic arrangements that support and are supported by psychology, the objective of such attention being to point to conditions that can fruitfully nurture psychological research, explanations, and healing practices that are aware of their embeddedness in the context in which they originate and circulate. The reorientation of psychology in Africa (and for African psychology students and scholars, towards Africa as the primary space of intellectual and politico-ethical engagement) is fundamentally to undo the hold of Euroamericentric psychology's totalising knowledge claims and frames, which remain for the most part racially organised and patriarchal in formation. The driving 'truth' claims of a critical African psychology are to be found in its making and doing of counter spaces - highlighting plurality and difference - where notions of transcendence and universality that classify and hierarchise knowledge and experience are disturbed through the pursuit of epistemic freedom (see Ndlovu-Gatsheni, 2018). This quest for epistemic independence is as much to consider, theorise, interpret, and author psychosocial liberation from the epistemic and material site of Africa, as it is to situate Africa as a legitimate actor of knowledge authority in psychology across the world. When rendered as a politico-epistemic authority - a knowing agent producing alternative cartographies of power - whose (trans)disciplinary intent curves expressly towards radical thought and praxis, critical African psychology students and scholars, as we observe in our own efforts, bear deep potential for the unfettering of African knowledge, imagination, and innovation in emancipatory service of African peoples.

The 'truth' claims of critical African psychology can be differentiated from the facts of exploitation, oppression, and injustice to which it addresses itself. For critical African psychology, 'truth' represents an epistemic, political, and methodological stance that can be taken up only when aligning with the emancipatory interests of society. In this way, psychosocial liberation is understood from a fundamentally partisan position (see Martín-Baró, 1994). Critical African psychology therefore does not understand psychosocial priorities in Africa as residing exclusively in conventional psychological spaces (e.g., the clinic or private practices) but in those collective struggles for liberation in Africa which are, at the same time, struggles for a more just world. These struggles need not always be in the realm of politics (they may relate to, for instance, representation, culture, communication, and even love), but they must be understood in relation to their politicising potential. The political issues on which we act are connected to the psychological issues to which we attend in our capacities as psychologists. Critical African psychology then obliges that we bridge these artificially segregated arenas (i.e., the political and the psychological) so that our praxis emerges from our positions as citizen-psychologist and psychologist-citizen.

The article presented three pathways - collective thinking and writing, transdisciplinarity, and affective community building - that are, in our collective (yet, importantly, neither totalising nor 
uniform) perspective, some of the routes through which to realise and work from a critical African psychological position. These are of course not all the routes available to critical African psychologists, psychology students, and organic intellectuals more generally. And the pathways are not equally applicable to all audiences. Some are more suited for researchers; some for therapists; some for teachers, supervisors, and students; and others for organic intellectuals and activist psychologists working within communities. All these pathways relate to what we refer to as enlarging the space of critical African psychology, and indeed the space within which such a psychology is done. In focusing on space, we have attempted to demonstrate in this article how critical African psychology is able to approach its 'truth' claims. More specifically, we have considered how the three pathways represent three courses, apparatuses, or accelerators through which critical African psychology can begin to extend itself into critically mediated epistemic, political, emotional, and physical spaces. Like the work of Fanon (1967a, 1967b), critical African psychology seeks to connect itself to psychosocial liberation in different ways, and thus must mould itself to the requirements of the agents of liberation. In this sense, critical African psychology remains attentive to the agency and suffering of the individual, but also to the everyday and larger struggles to overcome, while looking to connect the individual to the collective.

\section{Declaration of conflicting interests}

The author(s) declared no potential conflicts of interest with respect to the research, authorship, and/or publication of this article.

\section{Funding}

The authors received the following financial support for the research, authorship, and/or publication of this article: Financial support for research was received from the SAMRC-Unisa Masculinity \& Health Research Unit and the Unisa Institute for Social and Health Sciences.

\section{ORCID iD}

Kopano Ratele (iD https://orcid.org/0000-0002-1688-5136

\section{References}

Alexander, N. (2013). Thoughts on the new South Africa. Jacana.

Bhatia, S. (2002). Acculturation, dialogical voices and the construction of the diasporic self. Theory \& Psychology, 12(1), 55-77.

Canham, H. (2018). Theorising community rage for decolonial action. South African Journal of Psychology, 48(3), 319-330.

Danziger, K. (1997). Naming the mind: How psychology found its language. SAGE.

Dixon, J., \& Durrheim, K. (2000). Displacing place-identity: A discursive approach to locating self and other. British Journal of Social Psychology, 39(1), 27-44.

Enriquez, V. G. (1992). From Colonial to Liberation Psychology. University of the Philippines Press.

Fanon, F. (1967a). Black skin, white masks. Grove Press.

Fanon, F. (1967b). The wretched of the earth. Penguin Books.

Gergen, K. J. (2009). Relational being: Beyond self and community. Oxford University Press.

Gordon, L. R. (2007). Disciplinary decadence: Living thought in trying times. Taylor \& Francis.

Hook, D. (2005). A critical psychology of the postcolonial. Theory \& Psychology, 15(4), 475-503.

Hook, D. (Ed.). (2004). Critical psychology. UCT Press.

Lefebvre, H. (1991). The production of space. Blackwell.

Manganyi, N. C. (1973). Being-black-in-the-world. Ravan Press.

Martín-Baró, I. (1994). Writings for a liberation psychology. Harvard University Press. 
Masaka, D. (2018). The prospects of ending epistemicide in Africa: Some thoughts. Journal of Black Studies, 49(3), 284-301.

Massey, D. (2005). For space. SAGE.

Moane, G. (1999). Gender and colonialism: A psychological analysis of oppression and liberation. Macmillan.

Mohanty, C. T. (2003). Feminism without borders: Decolonizing theory, practicing solidarity. Duke University Press.

Montero, M., \& Sonn, C. C. (Eds.) (2009). Psychology of liberation: Theory and applications. Springer Science \& Business Media.

Mudimbe, V. Y. (1988). The invention of Africa: Gnosis, philosophy and the order of knowledge. Indiana University Press.

Mudimbe, V. Y. (1994). The idea of Africa. Indiana University Press.

Ndlovu-Gatsheni, S. J. (2018). Epistemic freedom in Africa: Deprovincialization and decolonization. Routledge.

Neely, B., \& Samura, M. (2011). Social geographies of race: Connecting race and space. Ethnic and Racial Studies, 34(11), 1933-1952.

Parker, I. (2007). Critical psychology: What it is and what it is not. Social and Personality Psychology Compass, 1(1), 1-15.

Rabaka, R. (2010). Against epistemic apartheid: WEB Du Bois and the disciplinary decadence of sociology. Lexington Books.

Ratele, K. (2017). Four (African) psychologies. Theory \& Psychology, 27(3), 313-327.

Ratele, K. (2019). The world looks this from here: Thoughts on African Psychology. Wits University Press.

Ratele, K., Cornell, C., Dlamini, S., Helman, R., Malherbe, N., \& Titi, N. (2018). Some basic questions about (a) decolonizing Africa(n)-centred psychology considered. South African Journal of Psychology, 48(3), 331-342.

Rodney, W. (1982). How Europe underdeveloped Africa. Howard University Press.

Rutherford, A., Capdevila, R., Undurti, V., \& Palmary, I. (Eds.). (2011). Handbook of international feminisms: Perspectives on psychology, women, culture, and rights. Springer Science \& Business Media.

Sehume, J. (2013). Transformation of cultural studies into transdisciplinarity. Critical Arts, 27(2), 163-181.

Slife, B. D., Reber, J. S., \& Richardson, F. C. (2005). Critical thinking about psychology: Hidden assumptions and plausible alternatives. American Psychological Association.

Soja, E. (2009). Taking space personally. In B. Warf \& S. Arias (Eds.), The spatial turn: Interdisciplinary perspectives (pp. 11-35). Routledge.

Stodulka, T. (2019). Orders of feelings. In J. Slaby \& C. von Scheve (Eds.), Affective societies: Key concepts (pp. 310-318). Routledge.

Teo, T. (2009). Philosophical concerns in critical psychology. In D. Fox, I. Prilleltensky, \& S. Austin (Eds.), Critical psychology: An introduction (pp. 36-53). SAGE.

Teo, T. (2015). Critical psychology: A geography of intellectual engagement and resistance. American Psychologist, 70(3), 243.

Valentine, G. (2001). Social geographies: Space and society. Pearson Education.

Valsiner, J., \& Rosa, A. (Eds.). (2007). The Cambridge handbook of sociocultural psychology. Cambridge University Press.

Williams, R. (1977). Marxism and literature. Oxford University Press.

Woodward, M., \& Phillips, J. (2019, November 1). Maggot and cow. Sydney Review of Books. https://sydneyreviewofbooks.com/essay/maggot-crow/

Wyatt, J., \& Gale, K. (2014). Introduction to the special issue on collaborative writing as method of inquiry. Cultural Studies - Critical Methodologies, 14(4), 295-397.

Young, J. C., \& Gilmore, M. P. (2013). The spatial politics of affect and emotion in participatory GIS. Annals of the Association of American Geographers, 103(4), 808-823.

Zeleza, P. T. (2006). The disciplinary, interdisciplinary and global dimensions of African studies. International Journal of African Renaissance Studies, 1(2), 195-220. 